\title{
Wood basic density effect of Eucalyptus grandis in the paper making
}

\author{
Victor Gonçalves Cremonez ${ }^{1,2}$, Eraldo Antonio Bonfatti Junior ${ }^{1}$, \\ Alan Sulato de Andrade ${ }^{1}$, Eliane Lopes da Silva ${ }^{1}$, \\ Ricardo Jorge Klitzke ${ }^{1}$, Umberto Klock ${ }^{1}$
}

\footnotetext{
${ }^{1}$ Engineering and Forestry Technology Department; Federal University of Paraná, Prefeito Lothário Meissner Avenue, 3400, Zip Code 80210-170, Curitiba, Paraná, Brazil.

${ }^{2}$ Faculty of Technology of Curitiba, Itacolomi Street, 450 Zip Code 81070-150, Curitiba, Paraná, Brazil. e-mail: victor.cremonez@gmail.com, bonfattieraldo@gmail.com, alansulato@gmail.com, eliane0103@gmail.com, rjkklitzke@gmail.com, klockuer@ufpr.br
}

\begin{abstract}
The basic density is the main technical property of the wood due to the fact of the easy determination and correlation with the others wood properties. In this article, it was evaluated wood chips from a five-years-old Eucalyptus grandis in three different silvicultural treatments for pulp and paper production. First, a conventional kraft pulping was executed in the same conditions and then submitted to some elemental chlorine free (ECF) bleaching process to achieve the target brightness of $88 \pm 1 \%$ ISO. The bleached pulps were refined in a Jokro Mill at 0, 2250, 4500 and 6750 revolutions and their physical, mechanical and optical properties were analyzed. The statistical analysis indicated a difference in the wood basic density from the different silvicultural treatments. The yield of the pulping process was not affected by the variation of the wood basic density. The denser wood had the advantage of a lower specific wood consumption while the disadvantage was a greater difficulty in the delignification and a decrease in the selectivity of the pulping process. The denser wood was the one with the best bleachability and the one that most consumed chlorine in the bleaching process. The increase of the wood density caused gains in the fisical and optical properties of the bleached pulp and losses in the mechanical properties. The optical properties of the pulps from denser woods are more resistant than the negative effects of mechanical properties.
\end{abstract}

Keywords: Kraft pulping; pulp bleaching; paper properties.

\section{INTRODUCTION}

Brazil is the world's largest producer of bleached eucalyptus pulp, the production of this type of cellulose pulp is intended for production of writing and printing papers besides the production of absorbent paper for hygienic purposes [1]. The production processes of these types of papers are distinct and require cellulosic pulps with different technical properties.

SANTOS and SANSÍGOLO [2] distinguish the ideal types of cellulose pulps for printing and writing paper and absorbent paper. In the first case, the most required demands are lower energy consumption in the mechanical refining, greater specific volume and greater opacity. In the case of absorbent papers manufacturing, the high capacity of water absorption and the increase of softness are important. Pulps from wood with lower basic densities are ideal for production of printing and writing paper, since they have fibers with smaller thickness and smaller mass per length. Pulps from denser hardwoods are ideal for absorbent paper, because they present fibers with greater thickness, therefore a greater potential of liquid absorption, and greater mass per length of fibers [2, 3].

The wood basic density is considered one of the most important parameters in the wood quality evaluation because of a strong relationship with others wood properties $[4,5,6]$. It is a physical property defined as the ratio between the absolutely dry wood weight and the saturated wood volume [7].

Variations in the wood basic density depend on the changes of the proportion of the vessels and cell wall thickness of the fibers. The density growth may result from the increase of the cell wall thickness in the fibers or an increase in the proportion of the fibers related to the proportion of vessels. On the other hand, an increase in the proportion of vessels, with or without cell wall thickness decrease, leads to a density reduction [8]. 
Considering the chemical composition of the wood DIAS and SILVA JÚNIOR [9], studying Eucalyptus grandis trees, found that the denser woods chemically showed an increase in the lignin content and a decrease in the polyses content, compared to the wood with lower densities.

Due to the strong effect in the variables of the pulping process and the characteristics of cellulose pulp and paper [2, 10], the wood basic density is directly applied in the pulp production. It is considered easy to determine and influence the process in the wood chipping; the impregnation of white cooking liquor, the reagents consumption and the rejects generation, creating a universal index to evaluate wood quality. However, it should be analyzed with discernment in order to not commit errors or exaggerations [11]. It may contain varieties in the radial and longitudinal directions in the shaft between the trees, the species, age, space and site [12].

There are several papers stating that the quality of pulp depends on the quality of the wood and the characteristics of the pulping process, however there are few papers evaluating this influence on young wood, that is, harvested before the traditional cutting age in the pulp and paper industry. In view of this the present work caracterizes the young wood of Eucalyptus grandis with different densities for pulp and paper production, for this the influence of the wood basic density in the pulping process, in the bleaching and in the paper properties was evaluated.

\section{MATERIALS AND METHODS}

It was used to carry out the present study, the wood of Eucalyptus grandis specie with five years old, in three different silvicultural treatments from The Pampas in Rio Grande do Sul, Brazil.

The three trees were removed from each treatment and it was obtained tree disks with $30 \%$ of the commercial height. These disks were reduced in chips that were used to determine the wood basic density and in the kraft pulping process. The wood chips were submitted to a thickness control between 4 and $6 \mathrm{~mm}$, different values of these impede the circulation of the chemical reagents as also the impregnation in the pulping process [13].

The wood basic density was determined by the mass weighing method and the indirect volume measurement according to the TAPPI T 258 om-16 [14] standard in 12 replicates.

The kraft cooking was carried out in a rotary autoclave containing individualized stainless steel capsules with a capacity of $1600 \mathrm{~mL}$ each. The assays were performed in three replicates according to the cooking conditions in Table 1.

Table 1: The kraft conditions in the pulping process.

\begin{tabular}{ll}
\hline Parameters & Conditions \\
\hline Alkali charge (NaOH base), \% & 22 \\
Sulfidity, \% & 25 \\
Maximum temperature, ${ }^{\circ} \mathrm{C}$ & 170 \\
Heating time, min & 90 \\
Cooking time, min & 60 \\
Liquor / wood ratio, $\mathrm{L} \mathrm{kg}^{-1}$ & 4 \\
H factor & 1100 \\
Dry mass of chips, $\mathrm{g}$ & 250 \\
\hline
\end{tabular}

After cooking, the pulps were disintegrated, washed and screened in a laboratory scrubber, with a 0.5 $\mathrm{mm}$ slit. The screened yield, the kappa number and the selectivity for each pulp were determined according to Table 2. 
Table 2: Determined parameters in the kraft pulping process.

\begin{tabular}{lc}
\hline Parameters & Standards / Procedures \\
\hline Pulping screened yield & Difference between the dry weight of screened \\
Kappa number & cellulose and dry weight of wood \\
Selectivity & TAPPI T 236 om-13 [15] \\
\hline
\end{tabular}

The specific wood consumption was determined by the relationship between the wood basic density and the pulping screened yield. It was calculated according to the Equation 1:

$$
\mathrm{SWC}=\left(\frac{1}{\mathrm{BD} \cdot \mathrm{SY}}\right)
$$

Note: SWC is the Specific Wood Consumption, BD is the Wood Basic Density and SY is the pulping screened yield.

Approximately $33 \mathrm{~g}$ of unbleached cellulose pulp was used for bleaching in each treatment of density. A four-stage bleaching sequence: D(EP)DP, aiming at $88 \pm 1 \%$ ISO as final brightness, are detailed in Table 3. All bleaching stages were performed in thermostated bath and the reactants were manually mixed with the cellullose pulp in polyethylene bag. The material was transferred to the thermostatized bath, the temperature controlled according to each stage and maintained in preset time. Among each stage, the pulps were washed in a ratio of nine cubic meters of water per ton of pulp.

Table 3: Conditions in the bleaching stages.

\begin{tabular}{lllll}
\hline \multirow{2}{*}{ Conditions } & \multicolumn{2}{c}{ Bleaching Stages } & & \\
\cline { 2 - 5 } & $\mathrm{D}$ & $\mathrm{EP}$ & $\mathrm{D}$ & $\mathrm{P}$ \\
\hline Consistency, $\%$ & 10 & 10 & 10 & 10 \\
Temperature, ${ }^{\circ} \mathrm{C}$ & 90 & 90 & 90 & 90 \\
Time, min & 60 & 60 & 60 & 60 \\
$\mathrm{ClO}_{2}, \mathrm{~kg} \mathrm{adt}^{-1}$ & $\mathrm{kf}=0.2^{*}$ & - & 20 & - \\
$\mathrm{NaOH}_{\mathrm{Ng} \mathrm{adt}}{ }^{-1}$ & - & 10 & - & 6 \\
$\mathrm{H}_{2} \mathrm{O}_{2}, \mathrm{~kg} \mathrm{adt}^{-1}$ & - & 5 & - & 2 \\
$\mathrm{MgSO}_{4}, \mathrm{~kg} \mathrm{adt}^{-1}$ & - & - & - & 3 \\
\hline
\end{tabular}

$\mathrm{D}=$ chlorine dioxide; $\mathrm{PE}=$ alkaline extraction with hydrogen peroxide; $\mathrm{P}=$ hydrogen peroxide; $*$ kappa factor: $\mathrm{ClO}_{2}$ loading $(\mathrm{kg}$ tsa-1) $=($ previous kappa $\cdot \mathrm{kf} \cdot 10) / 2.63$; adt $=$ air dry ton. 3:

The total of active chlorine and the pulp bleachability were calculated according to the equation 2 and

Total Active Chlorine $=\mathrm{D} \cdot 2.63+\mathrm{P} \cdot 2.09$

$$
\text { Bleachability }=\frac{\text { Brown pulp kappa number }}{\text { Total Active Chlorine }}
$$

Note: $\mathrm{D}$ is the total consumption of chlorine dioxide $\left(\mathrm{ClO}_{2}\right)$ on bleaching $\left(\mathrm{kg} \mathrm{adt}^{-1}\right)$; $\mathrm{P}$ is the total consumption of hydrogen peroxide $\left(\mathrm{H}_{2} \mathrm{O}_{2}\right)$ on bleaching $\left(\mathrm{kg} \mathrm{adt}^{-1}\right)$.

The refining of the bleached pulps was carried out in a Jokro Mill according to ISO 5267-3: 1979 [16], using the equivalent of 16 dry grains, $6 \%$ consistency, $\mathrm{pH} 7 \pm 0.5$, in a temperature of $30^{\circ} \mathrm{C}$ and refining degrees of $0,2250,4500$ and 6750 revolutions.

After the refining process, handsheets weighting $60 \mathrm{~g} \mathrm{~m}^{-2}$ were formed in Rapid-Köethen papermaker according to ISO 5269-2: 2004 [17]. The leaves were kept in an air-conditioned environment in a temperature of $23^{\circ} \mathrm{C} \pm 2{ }^{\circ} \mathrm{C}$ and $50 \% \pm 2 \%$ relative humidity [18]. Achieved the equilibrium with the environment, 
the leaves were destined to the physical-mechanical property tests. It was performed 10 repetitions for each test. The standards used for the tests are present in Table 4.

Table 4: Determined Parameters in bleached and refined pulps.

\begin{tabular}{lc}
\hline Parameters & Standards \\
\hline Thickness & TAPPI T220 sp-01 [19] \\
Specific volume (bulk) & TAPPI T220 sp-16[19] \\
Tensile index & TAPPI T494 om-13[20] \\
Burst index & TAPPI T403 om-15 [21] \\
Tear index & TAPPI T414 om-12 [22] \\
Brightness & ISO 2470-1:2016 [23] \\
Opacity & ISO 2471:2008 [24] \\
\hline
\end{tabular}

The resulting data were analyzed in the statistical software Statgraphics, where the tests of homogeneity and analysis of variance were realized and when significant difference was detected between treatments the Tukey test was used, at $5 \%$ of significance.

\section{RESULTS AND DISCUSSION}

\subsection{Wood basic density and pulping}

The average values obtained by the wood basic density of the Eucalyptus grandis from the three sites as also the cooking results are presented in Table 5.

Table 5: Wood basic density studies and cooking results from different densities.

\begin{tabular}{|c|c|c|c|c|}
\hline $\begin{array}{l}\text { Wood basic density } \\
\qquad \mathrm{g} \mathrm{cm}^{-3}\end{array}$ & $\begin{array}{c}\text { Screened yield } \\
\%\end{array}$ & Kappa number & $\begin{array}{l}\text { Specific wood consumption } \\
\qquad \mathrm{m}^{3} \mathrm{t}^{-1}\end{array}$ & Selectivity \\
\hline $0.381(4.93) \mathrm{a}$ & $45.71(6.42) \mathrm{a}$ & $6.00(2.93) \mathrm{a}$ & $5.76(6.34) b$ & $7.61(3.90) \mathrm{c}$ \\
\hline $0.407(2.99) b$ & $46.38(0.88) \mathrm{a}$ & $10.93(1.90) b$ & $5.30(0.93) a b$ & $4.24(1.93) b$ \\
\hline $0.436(3.04) \mathrm{c}$ & $48.08(4.21) \mathrm{a}$ & $14.00(3.87) \mathrm{c}$ & $4.79(4.18) \mathrm{a}$ & $3.44(3.20) \mathrm{a}$ \\
\hline
\end{tabular}

The values in parentheses correspond to the variant coefficients in percentage; the averages are followed by equal letters considering that the columns do not differ among themselves in the Tukey test with $5 \%$ probability.

The average values of the wood basic density presented statistical differences among the sites of origin. According to RIGATO et al. [25], it is possible to predict certain properties in the cellulose pulp through the analysis of the wood properties, which in turn are the result of site quality. This analysis can be reiterated by GOUVEA et al. [26] that determined basic densities with statistical differences for different sites, resulting in variations in the properties of the cellulose pulp from Eucalyptus grandis wood. The average values of the basic density found in the present study correspond with the literature. JESUS et al. [27] found in his studies from Eucaliptus grandis, values between 0.374 and $0.466 \mathrm{~g} \mathrm{~cm}^{-3}$ and BAROTO et al. [28] found an average value of $0.421 \mathrm{~g} \mathrm{~cm}^{-3}$.

The advances in the Brazilian silviculture and biotechnology allowed obtaining good quality wood that provide 50 to $54 \%$ pulp yield for densities varying from 0.500 to $0.520 \mathrm{~g} \mathrm{~cm}^{-3}$ [29]. In the present study the values of screened yield varied from 45 to $48 \%$. These results are lower than those found in the literature due to the fact that the wood used was considered of medium density, not exceeding $0.450 \mathrm{~g} \mathrm{~cm}^{-3}$.

No significant influence of basic wood density in the pulping yield was found, sustaining SANTOS and SANSÍGOLO [2], whose results were close in the present study. However, when QUEIROZ et al. [30] compared woods of Eucalyptus spp. with a broader difference in the density, found a significant influence on pulping yield. 
Aggregating the screened yield and the wood basic density, there is the specific wood consumption which expresses the necessary volume of wood for the production of determined cellulose pulp mass. In this study, the higher basic wood densities and the respective pulping screened yield resulted in a lower specific wood consumption. The same situation occurs with SEGURA and SILVA JÚNIOR [10] when they compared the pulping of a higher basic density wood with a lower basic density wood.

On the other hand, higher densities increased the kappa number, which expresses the degree of delignification of the pulp cellulose [15], as also seen by SEVERO et al. [31], and reduced the selectivity, considering that this parameter expresses the capacity to remove the lignin without attacking the wood carbohydrates, when the higher basic wood density, the greater is the degradation of carbohydrates.

\subsection{The bleaching of pulp}

The average results in the end of the bleaching are presented in Table 6. The kappa factor used in the first stage of the chlorine dioxide equalized the pulps in the subsequent stages at the cost of a greater application of active chlorine in the pulps originated from denser woods.

Table 6: Bleaching results in different densities.

\begin{tabular}{cccc}
\hline Wood basic density & Brightness, \% ISO & TAC, kg.tsa ${ }^{-1}$ & Bleachability \\
\hline D1 & 87.50 & 89.67 & 0.07 \\
D2 & 88.20 & 99.53 & 0.11 \\
D3 & 88.40 & 105.69 & 0.13 \\
\hline
\end{tabular}

$\mathrm{D} 1=0.389 \mathrm{~g} \mathrm{~cm}^{-3} ; \mathrm{D} 2=0.407 \mathrm{~g} \mathrm{~cm}^{-3} ; \mathrm{D} 3=0,436 \mathrm{~g} \mathrm{~cm}^{-3} ; \mathrm{TAC}=$ total active chlorine.

The bleachability is the ability of the pulp to respond the chemical bleaching treatments [32]. Considering this definition, it was observed in the present study that pulps with higher kappa numbers, originated from denser woods, presented a better response to the bleaching. At the cost of higher consumption of total active chlorine, that means a expensive and more polluting bleaching for denser woods pulps.

\subsection{Paper properties}

According to TEIXEIRA et al. [33], refining is a mechanical treatment which the pulp fibers are ruptured in fibrils, increasing in the fiber surface area. Consequently, when the paper is formed, a larger contact surface area and a greater interlacement among the fibrils are obtained. The energy used in the refining causes changes in the fibers and leaves them more susceptible to collapse in the paper forming process as also decreases sheet thickness and specific volume.

In the present study the thickness of the leaves in all densities decreased more intensely, up to 2250 revolutions (Figure 1). From that point on, stabilization in this parameter was observed and the specific volume also had an accentuated decrease initially followed by stabilization (Figure 2).

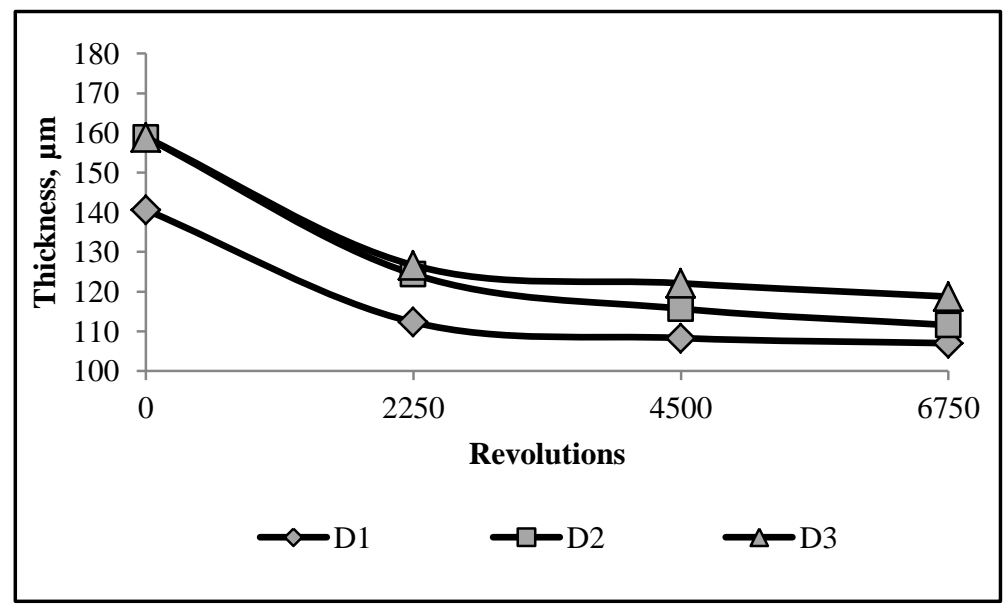

Figure 1: Variation in handsheet thickness. 


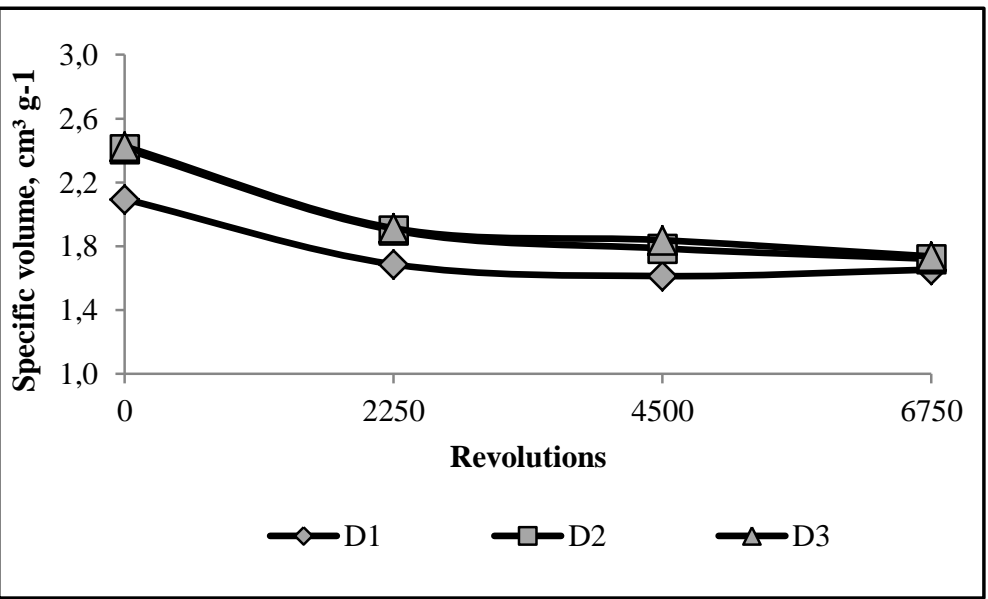

Figure 2: Variation in Handsheet specific volume (bulk).

In both figures it is possible to observe that the leaves from denser wood presented a greater thickness and specific volume. Considering the positive relation between basic density and fiber thickness [34], the fibers of the higher density wood have a larger wall fraction [35] and this promoted greater resistance to the effect of refining and, therefore, greater resistance to collapse, increasing the thickness of the sheet and its specific volume.

The table 7 shows the influence of the wood basic density into the effect of refining in the mechanical properties of the paper. The results of tensile index didn't show a clear trend of the effect the wood basic density. On the other hand in the tear index and burst index D2 had grater values with increasing refining intensity, therefore D2 pulps require a lower number of revolutions to reach the same tear index or burst index than the pulps D1 and D3, evidencing lower energy consumption in the refining and, consequently, cheaper paper production.

The main purpose of refining is to increase the interlacement capacity among the fibers in such a way that they can create a strong network [36]. Refining improves the paper mechanical properties but it should not be in excess because it can damage the fibers and reduce the mechanical properties of the paper.

The three mechanical properties analyzed led to an increase in the number of revolutions, up to 2250 revolutions. This increase was more accentuated than those that occurred in the following stages (Figure 3, Figure 4 and Figure 5). The influence of the refining in the mechanical properties of the paper obtained in this study was the same as the one found by CARVALHO et al. [31] and ZANUNCIO et al. [37].

Table 7: Mechanical properties of the paper in different densities and revolutions.

\begin{tabular}{ccccc}
\hline \multirow{2}{*}{ Wood basic density } & Revolutions & TEI & TEAR & BUI \\
\hline \multirow{2}{*}{ D1 } & 0 & $31.61 \mathrm{~d}$ & $6.27 \mathrm{f}$ & $2.12 \mathrm{f}$ \\
& 2250 & $50.36 \mathrm{bc}$ & $8.70 \mathrm{cde}$ & $3.62 \mathrm{e}$ \\
& 4500 & $50.46 \mathrm{bc}$ & $8.32 \mathrm{de}$ & $3.99 \mathrm{de}$ \\
& 6750 & $59.79 \mathrm{a}$ & $10.58 \mathrm{~b}$ & $4.56 \mathrm{bc}$ \\
\hline \multirow{2}{*}{ D2 } & 0 & $21.60 \mathrm{e}$ & $3.81 \mathrm{~g}$ & $1.68 \mathrm{~g}$ \\
& 2250 & $49.55 \mathrm{c}$ & $7.77 \mathrm{e}$ & $4.00 \mathrm{de}$ \\
& 4500 & $55.72 \mathrm{abc}$ & $9.50 \mathrm{bcd}$ & $4.97 \mathrm{ab}$ \\
& 6750 & $59.65 \mathrm{a}$ & $12.96 \mathrm{a}$ & $5.10 \mathrm{a}$ \\
\hline & 0 & $23.90 \mathrm{de}$ & $3.25 \mathrm{~g}$ & $1.68 \mathrm{~g}$ \\
& 2250 & $51.36 \mathrm{abc}$ & $8.82 \mathrm{cde}$ & $3.96 \mathrm{de}$ \\
& 4500 & $56.46 \mathrm{abc}$ & $9.07 \mathrm{cde}$ & $4.24 \mathrm{~cd}$ \\
& 6750 & $58.33 \mathrm{ab}$ & $9.37 \mathrm{bc}$ & $4.47 \mathrm{c}$ \\
\hline
\end{tabular}


TEI = tensile index, $\mathrm{Nm} \mathrm{g}^{-1} ;$ TEAR $=$ tear index, $\mathrm{mNm}^{2} \mathrm{~g}^{-1} ; \mathrm{BUI}=$ burst index, $\mathrm{kPam}^{2} \mathrm{~g}^{-1}$, the averages are followed by equal letters considering that the columns do not differ among themselves in the Tukey test with $5 \%$ probability.

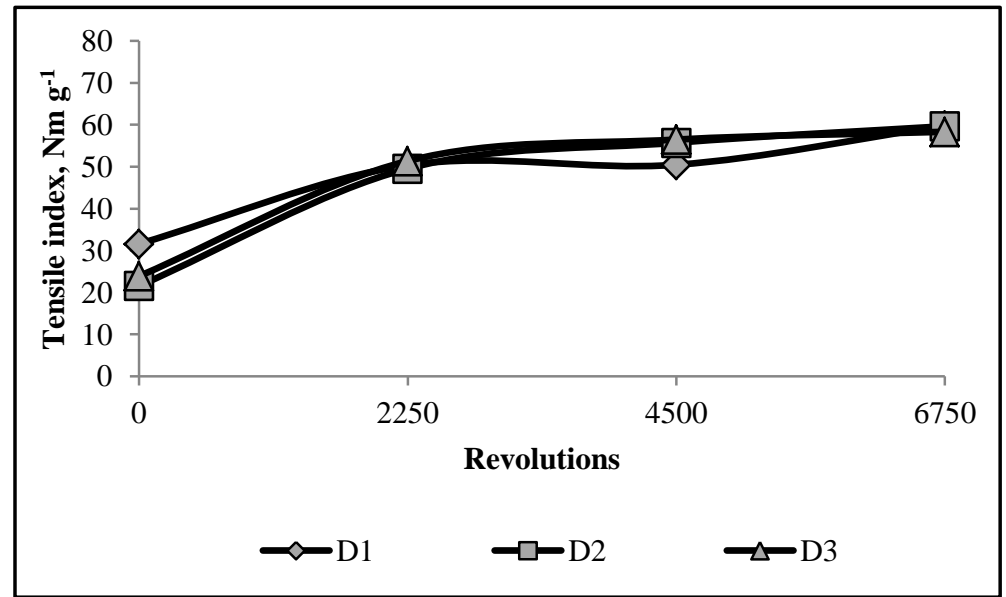

Figure 3: Variation in tensile index.

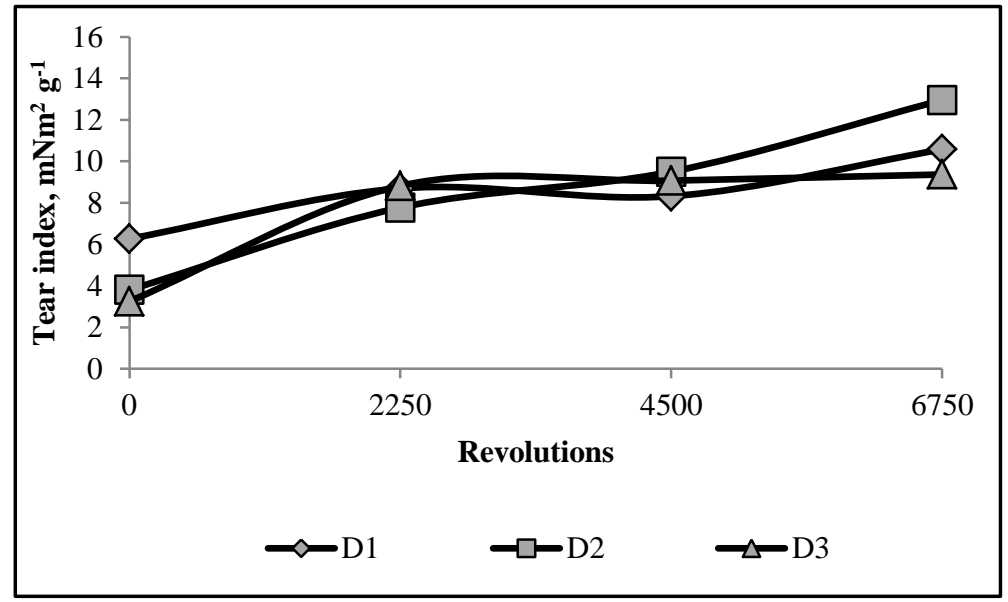

Figure 4: Variation in tear index.

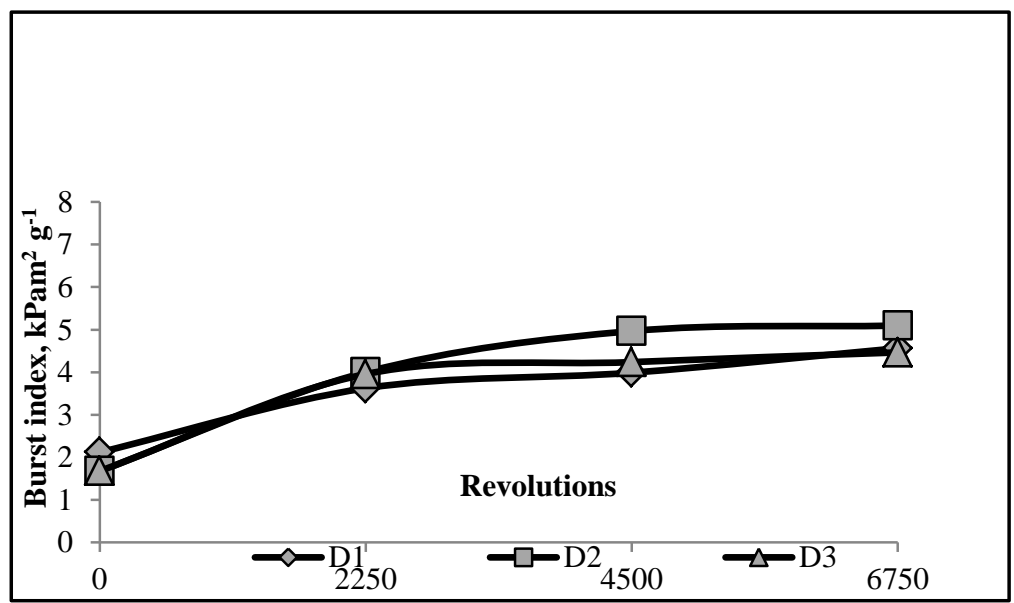

Figure 5: Variation in burst index.

The Table 8 presents the results of the optical properties: the brightness and the opacity, in three distinct densities and in four refining levels. MACDONALD [38] recommend that when looking for pulps of 
high brightnes is necessary to avoid exaggerations in the mechanical refining, because it causes a decrease in the brightness and in the opacity.

Table 8: Optical properties of the paper in different densities and revolutions.

\begin{tabular}{cccc}
\hline \multirow{2}{*}{ Wood basic density } & Revolutions & Brightness, \% ISO & Opacity, \% \\
\hline \multirow{2}{*}{ D1 } & 0 & $87.49 \mathrm{bc}$ & $90.43 \mathrm{a}$ \\
& 2250 & $86.05 \mathrm{~d}$ & $88.13 \mathrm{c}$ \\
& 4500 & $84.56 \mathrm{f}$ & $87.22 \mathrm{e}$ \\
& 6750 & $83.56 \mathrm{~g}$ & $87.35 \mathrm{de}$ \\
\hline \multirow{2}{*}{ D2 } & 0 & $88.16 \mathrm{ab}$ & $90.38 \mathrm{a}$ \\
& 2250 & $86.37 \mathrm{~d}$ & $87.81 \mathrm{~cd}$ \\
& 4500 & $85.33 \mathrm{e}$ & $86.68 \mathrm{fg}$ \\
& 6750 & $85.73 \mathrm{de}$ & $86.14 \mathrm{~g}$ \\
\hline & 0 & $88.42 \mathrm{a}$ & $90.79 \mathrm{a}$ \\
& 2250 & $87.38 \mathrm{c}$ & $88.73 \mathrm{~b}$ \\
& 4500 & $86.20 \mathrm{~d}$ & $88.19 \mathrm{c}$ \\
& 6750 & $85.76 \mathrm{de}$ & $87.10 \mathrm{ef}$ \\
\hline
\end{tabular}

The averages are followed by equal letters considering that the columns do not differ among themselves in the Tukey test with $5 \%$ probability.

In the present study, the pulps originated from denser wood maintained a better brightness after the mechanical refining. It is possible to observe it in Figure 6.

Opacity can be explained by the ability of the material to prevent the passage of light and indicates how well a sheet can hide an impression that is made on its backside [39]. The unrefined pulps have a high fraction of empty spaces in the interior. Since the light needs to pass through two ways, the air and the fiber wall tend to be diffracted and dissipated [40]. In the refined pulps there is practically only the cellular wall from the internal fibers. The light needs to pass through only one way, it becomes easier and therefore the opacity decreases [37].

Figure 7 shows the trend found in this work. The opacity did not present any statistical diference among the densities before the refining process.The result agreed with SANTOS and SANSÍGOLO [2]. However, a higher wood density pulp kept a better opacity in front of the mechanical refining, followed by a lower basic wood density pulp.

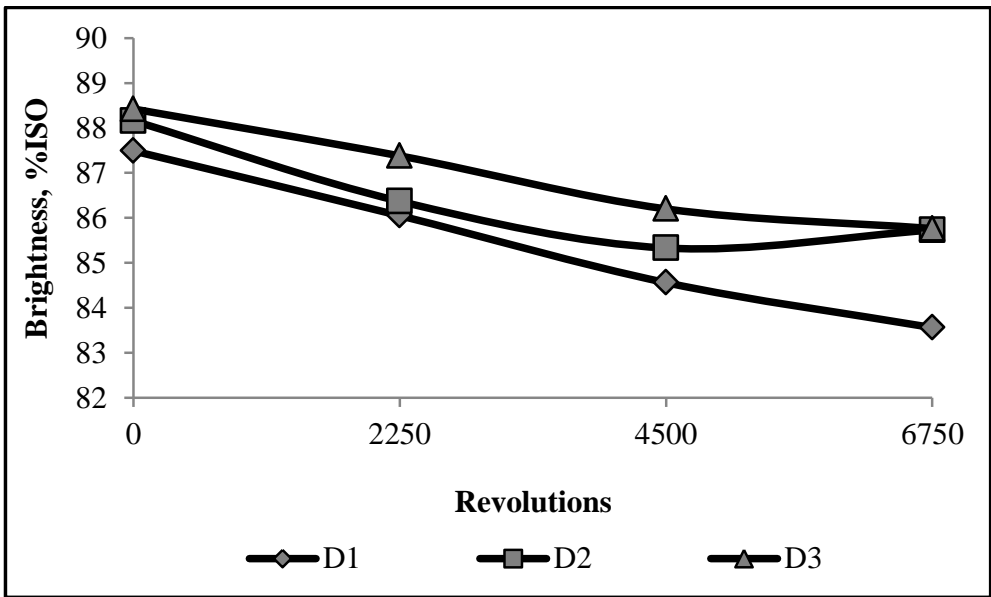

Figure 6: Decrease in the paper brightness in the mechanical refining. 


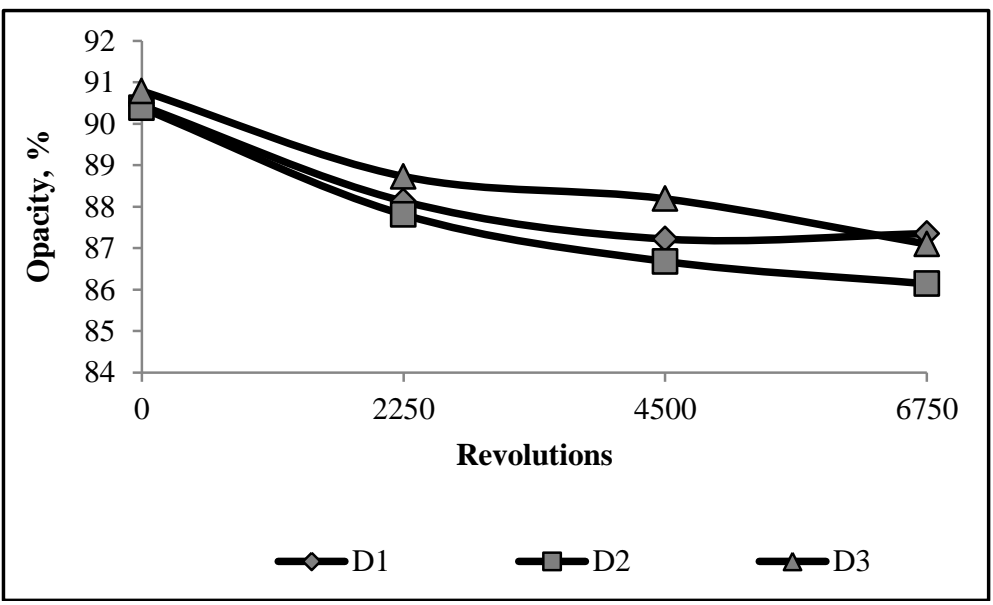

Figure 7: Decrease in the paper opacity in front of the mechanical refining.

The opacity did not present any statistical difference among the densities before the refining process. The result agrees with SANTOS and SANSÍGOLO [2].

\section{CONCLUSIONS}

Considering the same cooking conditions, the increase of the wood basic density did not promote variations in the pulp yield, however, the denser wood presented a lower specific consumption, made it difficult to delignify and harmed the selectivity of the pulping process.

In the bleaching process, the pulp from the denser wood presented greater bleachability, on the other hand, it consumed more chlorine to reach the predetermined brightness.

In the mechanical paper properties the best results were found in the pulp from medium wood basic density.

The increase in the basic density of wood resulted in increases in paper thickness, specific volume, brightness and opacity.

The pulp from the denser wood was the one that suffered lesser losses in the brightness after the mechanical refining.

\section{ACKNOWLEDGEMENTS}

The authors are grateful to the Pulp and Paper Laboratory team from Federal University of Paraná for all the support in this paper.

\section{BIBLIOGRAPHY}

[1] INDÚSTRIA BRASILEIRA DE ÁRVORES - IBÁ. Relatório anual 2017. Brasília, IBÁ, 2017.

[2] SANTOS, S.D., SANSÍGOLO, C.A. "Influência da densidade básica da madeira de clones de Eucalyptus grandis x Eucalyptus urophylla na qualidade da polpa branqueada", Ciência Florestal, v. 17, n. 1, pp. 53-63, jan-mar. 2007.

[3] MOKFIENSKI, A., COLODETTE, J.L., GOMIDE, J.L., et al., "A importância relativa da densidade da madeira e do teor de carboidratos no rendimento de polpa e na qualidade do produto", Ciência Florestal, v. 18, n. 3, pp. 401-413, jul-set. 2008.

[4] SCANAVACA JUNIOR, L., GARCIA, J.N. "Determinação das propriedades físicas e mecânicas da madeira de Eucalyptus urophylla", Scientia Forestalis, n. 65, pp. 120-129, jun. 2004.

[5] TRUGILHO, P.F., SILVA, J.R.M., LIMA, J.T., et al., "Rendimentos e características do carvão vegetal em função da posição radial da amostragem em clones de Eucalyptus", Cerne, v. 11, n. 2, pp. 178-186, 
abr./jun. 2005.

[6] HORÁČEK, P., FAJSTAVR, M., STOJANOVIĆ, M. "The variability of wood density and compression strength of Norway spruce (Picea abies /L./ Karst.) within the stem", Beskydy, v. 10, n. 1-2, pp. 17-26, 2017.

[7] ASSOCIAÇÃO BRASILEIRA DE NORMAS TÉCNICAS. NBR 11941: Densidade Básica da Madeira. Rio de Janeiro, 2003.

[8] OLIVIRA, J.T.S., SILVA, J.C. "Variação radial da retratibilidade e densidade básica da madeira de $E u$ calyptus saligna Sm.”, Revista Árvore, v. 27, n. 3, pp. 381-385, maio/jun. 2003.

[9] DIAS, V.R.L., SILVA JÚNIOR, C.E. "A influência da densidade básica da madeira de híbridos de Eucalyptus grandis em suas características químicas, e propriedades de polpação e do papel”, In: Congresso anual da associação brasileira técnica de celulose e papel, pp. 31-55, São Paulo, out. 1985.

[10] SEGURA, T.E.S., SILVA JÚNIOR, F.G. "Potential of C.citriodora for kraft pulp production", TAPPI Journal, v. 15, n. 3, pp. 159-164, mar. 2016.

[11] FOELKEL, C.E.B., MORA, E., MENOCHELLI, S. "Densidade básica: sua verdadeira utilidade como índice de qualidade da madeira de eucalipto para produção de celulose", $O$ Papel, v. 53, n. 35-40, p. 5, set. 1992.

[12] DE ALENCAR, G.S.B., BARRICHELLO, L.E.G., SILVA JÚNIORR, F. G. "Qualidade da madeira de híbrido de E. grandis x E. urophylla e seleção precoce", In: Congresso anual da associação brasileira técnica de celulose e papel, pp. 1-6, São Paulo, out. 2001.

[13] KOCUREK, M.J. Mill control and control systems: quality and testing, environmental corrosion, electrical systems. Atlanta, TAPPI Press, 1992.

[14] TECHNICAL ASSOCIATION OF PULP AND PAPER INDUSTRY. T 258 om-16: Basic density and moisture content of pulpwood. Atlanta, 2016.

[15] TAPPI - TECHNICAL ASSOCIATION OF PULP AND PAPER INDUSTRY. T 236 om-13: Kappa number of pulp. Atlanta, 2013.

[16] INTERNATIONAL ORGANIZATION FOR STANDARDIZATION ANONYMOUS. ISO 52673:1979: Pulps - Laboratory beating - Part 3: Jokro mill method. Genebra, 2008.

[17] INTERNATIONAL ORGANIZATION FOR STANDARDIZATIO. ISO 5269-2:2004: Pulps - Preparation of laboratory sheets for physical testing - Part 2: Rapid-Köthen method. Genebra, 2008.

[18] TECHNICAL ASSOCIATION OF PULP AND PAPER INDUSTRY. T 402 sp-03: Standard conditioning and testing atmospheres for paper, board, pulp handsheets and related products. Atlanta, 2003.

[19] TECHNICAL ASSOCIATION OF PULP AND PAPER INDUSTRY. T 220 sp-16: Physical testing of pulp handsheets. Atlanta, 2016.

[20] TECHNICAL ASSOCIATION OF PULP AND PAPER INDUSTRY. T 494 om-13: Tensile properties of paper and paperboard (using Constant rate of elongation apparatus). Atlanta, 2013.

[21] TECHNICAL ASSOCIATION OF PULP AND PAPER INDUSTRY. T 403 om-15: Bursting strength of paper. Atlanta, 2015.

[22] TECHNICAL ASSOCIATION OF PULP AND PAPER INDUSTRY ANONYMOUS. T 414 om-12: Internal tearing resistance of paper (Elmendorf-type method). Atlanta, 2012.

[23] INTERNATIONAL ORGANIZATION FOR STANDARDIZATION. ISO 2470-1:2016: Paper, board and pulps - Measurement of diffuse blue reflectance factor - Part 1: Indoor daylight conditions (ISO brightness). Genebra, 2016.

[24] INTERNATIONAL ORGANIZATION FOR STANDARDIZATION. ISO 2471:2008: Paper and board -- Determination of opacity (paper backing) -- Diffuse reflectance method. Genebra, 2008.

[25] RIGATO, P.A., DEDECEK, R.A., MATOS, J.L.M. "Influência dos atributos do solo sobre a qualidade da madeira de Pinus taeda para produção de celulose kraft", Revista Árvore, v. 28, n. 2, pp. 267-273, mar./abr. 2004.

[26] GOUVEA, A.F.G., GOMES, C.M., MATOS, L.M., et al., "Efeito do sítio nas características tecnológicas da madeira de eucalyptus para produção de celulose Kraft", Ciência da Madeira, v. 3, n. 2, pp. 102-115, nov. 2012.

[27] JESUS, M.S., COSTA, L.J., FERREIRA, J.C., et al., "Caracterização energética de diferentes espécies de Eucalyptus", Floresta, v. 47, n. 1, pp. 11-16, jan./mar. 2017.

[28] BAROTTO, A.J., MONTEOLIVA. S., GYENGER, J., et al., "Wood density and anatomy of three Eu- 
calyptus species: implications for hydraulic conductivity", Forestry Systems, v. 26, n. 1, pp. 1-11, abr. 2017. [29] BASSA, A.G.M.C., SILVA JÚNIORR, F.G., SACON, V.M. "Misturas de madeira de Eucalyptus grandis x Eucalyptus urophylla e Pinus taeda para produção de celulose kraft através do Processo Lo-Solids®", Scientia Forestalis, n. 75, pp. 19-29, set. 2007.

[30] QUEIROZ, S.C.S., GOMIDE, J.L., COLODETTE, J.L., et al., "Influência da densidade básica da madeira na qualidade da polpa kraft de clones hibrídos de Eucalyptus grandis W. Hill ex Maiden X Eucalyptus urophylla S. T. Blake", Revista Árvore, v. 28, n. 6, pp.901-909, nov./dez. 2004.

[31] SEVERO, E.T.D., SANSIGOLO, C.A., CALONEGO, F.W., et al., "Kraft pulp from juvenile and mature woods of Corymbia citriodora", Bioresources, v. 8, n. 2, pp. 1657-1664, maio. 2013.

[32] CARVALHO, D.M., SILVA, M.R., COLODETTE, J.L. "Estudo da branqueabilidade da polpa kraft de eucalipto", Ciência Florestal, v. 25, n. 1, pp. 185-197, jan./mar. 2015.

[33] TEIXEIRA, M.B.D., OLIVEIRA, R.A., GATTI, T.H., SUAREZ, P.A.Z. "O Papel: uma breve revisão histórica, descrição da tecnologia industrial de produção e experimentos para obtenção de folhas artesanais", Revista Virtual de Química, v. 9, n. 3, pp. 1364-1380, maio./jun. 2017.

[34] LARSON, P.R., KRETSCHMANN, D.E., CLARK, A., et al., Formation and properties of juvenile wood in southern pines: a synopsis, In: FPL research report, n. 129, USDA. Forest Service, Washington, D.C., 2001.

[35] PAULINO, P.S., LIMA, I.L. "Densidade básica e dimensões celulares da madeira em clones de Eucalyptus urophylla aos oito anos de idade", Ciência da Madeira, v. 9, n. 1, pp. 9-1, mar. 2018.

[36] SWINEHART, D. Fundamentals of Refining. Rayleigh, MeadWestvaco Center for Packaging Innovation, 2012.

[37] ZANUNCIO, A.J.V., CARVALHO, A.G., DAMÁSIO, R.A.P., et al., "Avaliação das propriedades físicas, mecânicas e ópticas da polpa celulósica durante refino", Ciência da Madeira, v. 7, n. 2, pp. 81-87, ago. 2016.

[38] MACDONALD, R.G. The pulping of wood. 2. ed., New York, Mcgraw-Hill Inc., 1968.

[39] BOULDER, C. Optical and appearence properties in handbook of physical testing of paper. 2. ed., New York, Marcel Dekker Inc., 2001.

[40] SCOTT, W.E., ABBOTT, J.C. Properties of paper: an introduction. 2. ed., Atlanta, TAPPI Press, 1995.

\section{ORCID}

Victor Gonçalves Cremonez

Eraldo Antonio Bonfatti Júnior

Alan Sulato de Andrade

Eliane Lopes da Silva

Ricardo Jorge Klitzke

Umberto Klock https://orcid.org/0000-0001-6396-7145

https://orcid.org/0000-0002-2730-7681

https://orcid.org/0000-0003-1574-9623

https://orcid.org/0000-0003-2876-8137

https://orcid.org/0000-0001-6839-9415

https://orcid.org/0000-0003-3946-3320 